\author{
$\stackrel{\odot}{\|}$

\section{NADZOROWAĆ I KSZTALTOWAĆ. WYMIARY SPOŁECZEŃSTWA SIECIOWEGO}

\begin{abstract}
Mariusz Baranowski, Piotr Luczys, Nadzorowaći kształtować. Wymiary społeczeństwa sieciowego [Discipline and shape. Dimentions of network society], edited by M. Baranowski ,, Człowiek i Społeczeństwo", vol. XL, Poznań 2015, pp. 13-27, Adam Mickiewicz University Press. ISBN 978-83232-2964-3, ISSN 0239-3271.
\end{abstract}

The purpose of this article is to show the different possibilities of applying supervision in the network society, which seems to be particularly susceptible to these types of practices. The scope and forms of social control in the dimension of the network will be discussed at both the level of individual applications of the generally available tools, as well as at the more sophisticated system of specialized programs. Apart from the perspective of surveillance in terms of advanced technology, the possible defensive tendencies also will be presented.

Mariusz Baranowski, Uniwersytet im. Adama Mickiewicza w Poznaniu, Instytut Socjologii, ul. Szamarzewskiego 89c, 60-569 Poznań, Poland, e-mail: mariusz.baranowski@amu.edu.pl

Piotr Luczys, Uniwersytet im. Adama Mickiewicza w Poznaniu, Instytut Socjologii, ul. Szamarzewskiego 89c, 60-569 Poznań, Poland, e-mail: piotr.luczys@amu.edu.pl

„Inwigilacja” i „zarządzanie populacją” stają się dziś lingua franca sprawowania i wykonywania władzy także w pozapolitycznym sensie tego pojęcia. Jako jej najnowsze postacie posługują się zupełnie innym instrumentarium niż XX-wieczne systemy dyscyplinowania i represji, totalitarne nadzorowanie terytoriów oraz pierwsze próby rozproszenia ośrodków kontroli i nadzoru, co nie oznacza wcale, że ich zasięg jest mniejszy, a efekty 
oddziaływania nie tak rozległe. Kapilarnie pojmowana władza ${ }^{1}$ - właściwa współczesności - za swoje dominium, medium komunikacji, a zarazem środowisko działania przyjęła cyfrową sieć, coraz szczelniej oplatającą wszystkie środowiska życia człowieka². O ile jeszcze kilka lat temu, mówiąc o czymkolwiek, co dotyczy aktywności człowieka, można było być prawie pewnym, że dotyczy to działań w sferze miejskiej’ o tyle dziś - w większości przypadków - możemy mieć pewność, że dany proces przebiega symultanicznie w Sieci, przy jej współudziale lub że Sieć stanowiła środowisko jego symulacyjnej realizacji jeszcze przed przystąpieniem do „rzeczywistego” działania. Wzrasta także liczba aktywności, które rozwijają się wyłącznie w Sieci, a których „zewnętrznym” przejawem stają się dopiero ich efekty, generujące w rzeczywistości społecznej nowe rezerwuary znaczeń (kategoria „zjawisk” i „osobliwości” internetowych), problemów i syndromów (np. efekt Streisand), umiejętności i kompetencji (np. UX, projektowanie sieciowe), schorzeń i patologii (np. Internet Addiction Disorder, socjomania internetowa), podziałów społecznych (np. wykluczenie cyfrowe, standard Responsive Web Design) czy też technologicznych przekształceń (np. dostęp do urządzeń mobilnych, szybkiego Internetu, chmur obliczeniowych i form współdzielenia przestrzeni sieciowej). Można nawet zaryzykować twierdzenie, że pozornie anarchiczny i niezwykle liberalny świat sieci elektronicznej został jeszcze szybciej zasiedlony przez nowe kategorie gatekeeperów, dozorców, dysponentów i właścicieli (pomimo swojej rozłożystości rozmiarami wielokrotnie przekraczający pojemność rzeczywistości) niż świat niecyfrowy. Akceleracja obiegu informacji stworzyła możliwość jeszcze szybszego opanowywania elektronicznych terytoriów i wprowadzania władzy nad jej jeszcze niezajętymi fragmentami ${ }^{4}$. Jedynym, co ratuje Sieć

${ }^{1}$ M. Foucault, Bezpieczeństwo, terytorium, populacja. Wykłady z Collège de France 1977/1978, Warszawa 2010; idem, Narodziny biopolityki. Wykłady z Collège de France 1978/1979, Warszawa 2012; idem, Rzq̨dzenie żywymi. Wykłady z Collège de France 1979/ 1980, Warszawa 2014.

${ }^{2}$ Ch. Jonscher, Życie okablowane. Kim jesteśmy w epoce przekazu cyfrowego?, Warszawa 2001.

${ }^{3}$ Por. K. Nawratek, Dziury w całym. Wstęp do miejskich rewolucji, Warszawa 2012. Według raportów na temat światowej urbanizacji (np. „Urban Report” Massachusetts Institute of Technology, „Global Trends” czy „European Cities Monitor”) około 60\% ludzkości mieszka w miastach (stan na rok 2010), a do 2025 r. odsetek ten ma się zwiększyć do ok. 75\%. Por. W. Moore, Futurecities - the survival of the fastest, Institute of Directors, 2012, http://www.iod.com/ /media/Documents/PDFs/Influencing/Big\%20Picture/BP\%202012/ futurecitiesthesurvivalofthefastestdec12.pdf [16.12.2014].

${ }^{4}$ Por. J. Gleick, Szybciej. Przyspieszenie niemal wszystkiego, Poznań 2003; idem, Informacja. Bit, wszechświat, rewolucja, Kraków 2012. 
przed byciem zwierciadłem rzeczywistości, jest możliwość dalszego multiplikowania przestrzeni cyfrowej, a co za tym idzie - generowania nowych obszarów, które może zasiedlić czyjaś/jakaś władza. Możliwości świata realnego wydają się w tym zakresie skończone. Co więcej, Sieć nie wspiera dziś rzeczywistości (czy raczej: nie ogranicza się wyłącznie do wspierania rzeczywistości), lecz przebiega obok niej, stanowiąc dla niej coraz częściej nowe „obciążenie”, nowy kontekst, z którym należy sobie poradzić; kolejny element „nadbudowy”, w ramach którego poczynione zmiany oczekują swego upostaciowienia w świecie realnym. Dlatego też analizując dziś społeczeństwo informacyjne ${ }^{5}$, nie powinniśmy mówić jedynie o informacji (jej obiegu i przetwarzaniu), lecz o dialektyce egzystowania na pograniczu dwóch światów - cyfrowego i realnego, których wzajemne przenikanie prowadzi do powstawania zupełnie nowych sytuacji społecznych.

Co jednak z samą władzą polityczną, stanowiącą - na gruncie klasycznych definicji - przedmiot umowy społecznej lub Hobbesowskiego „paktu”'? Zgodnie z nimi władza jest „powierzana”, za obopólną zgodą, jednej ze stron, a tym, co je odróżnia, jest jej zakres - stopień, w jakim posiada ją jedna strona, jest równy stopniowi, w jakim druga strona jest jej pozbawiona. W tym sposobie rozumienia można umiejscowić wiele XIX-wiecznych koncepcji władzy, ale i teorie koercyjne (np. Ralfa Dahrendorfa), Talcotta Parsonsa, Richarda Emersona i wielu innych ${ }^{7}$. Każdorazowo chodzi o pewien „dystans” i „dysproporcję”, a zarazem możliwość wywierania wpływu, modyfikowania zachowania, „czynienia swojej woli”, niekoniecznie w zgodzie z wolą innych, w rozumieniu Maxa Webera ${ }^{8}$. Mówiąc jednak o społeczeństwie informacyjnym, dla którego naturalne są dwa środowiska życia, często jednocześnie (Sieć i rzeczywistość), musimy zdawać sobie sprawę, że o władzy nie można już myśleć w kategoriach odległości, różnic i asymetrii, ponieważ posługiwanie się nimi pozwala myśleć, że istnieje pewien obiektywny punkt odniesienia, zgodnie z którym możliwa jest

${ }^{5}$ O relacji między społeczeństwem informacyjnym a sieciowym zob. M. Baranowski, Przyczynek do krytyki społeczeństwa sieciowego: od sieci społecznych do sieci wszystkich sieci, w: M. Baranowski, B. Mika (red.), Społeczeństwo sieciowe - między wolnościq a zniewoleniem, Poznań 2012, ss. 15-31.

${ }^{6}$ T. Hobbes, Lewiatan, Warszawa 2005.

${ }^{7}$ Por. J. Mucha, K. Müller, Ralfa Dahrendorfa konfliktowa wizja społeczeństwa. Wprowadzenie do Klas i konfliktu klasowego w społeczeństwie przemysłowym, w: R. Dahrendorf, Klasy i konflikt klasowy w społeczeństwie przemysłowym, Kraków 2008, ss. IXXXXIII.

${ }^{8}$ M. Weber, Gospodarka i społeczeństwo. Zarys socjologii rozumiejq̨cej, Warszawa 2002, ss. 158-161, 682-687. 
ocena, kto pełni w społeczeństwie rolę nadrzędną, a kto podrzędną. Innymi słowy, istnieje możliwość hierarchizacji członków populacji (lub jej grup), z uwzględnieniem dystansów między poszczególnymi szczeblami władzy, a wywieranie wpływu przebiega wyłącznie w sposób wertykalny - z góry na dół. Zakłada się powszechnie, że władza istniejąca w Sieci jest (za to) władzą horyzontalną, której węzłowe punkty mogą mieć zupełnie inne usytuowanie w wertykalnej strukturze władzy rzeczywistości. Biorąc pod uwagę amalgamiczny charakter Sieci, możliwe jest nawet istnienie w niej wielu odrębnych struktur władzy, których częściowe przenikanie do świata realnego reformatuje właściwe dla niej struktury nadrzędności i podrzędności. Proces ten zachodzi rzecz jasna w obie strony. Jego siłą napędową jest dążenie do wywierania wpływu, a głównym nośnikiem - informacja9 ${ }^{9}$. Próba analizy sieciowych technologii, określanych jako współczesne systemy nadzoru, może doprowadzić jednak nie do „horyzontalnych” struktur władzy, a - tych jakże heurystycznie mało interesujących - wertykalnych, choć działających w sferze „podskórnej”, tzn. nieuświadamianej przez obywateli i innych członków społeczeństw:

Brak bezpośrednich (widocznych) śladów wykorzystywania nowych technologii do celów raczej ograniczania niźli poszerzania sfery autonomii podmiotów korzystających z tej jakże poręcznej infrastruktury stanowi o „doskonałości” (tj. niewidoczności) tego instrumentarium. Wspomniana „doskonałość” jest rezultatem oddziaływania całego spektrum narzędzi (także mniej wyrafinowanych od teleinformatycznych zdobyczy), które systematycznie i konsekwentnie kreują skomplikowane współzależności ${ }^{10}$.

Jak zatem możliwe jest wykreowanie silnego ośrodka scentralizowanej władzy w środowisku sieciowym, mogącego dyscyplinować społeczeństwo informacyjne? I czy towarzyszy temu zgoda rzeczonej społeczności? Przeróżni sieciowi „strażnicy bram” (gatekeepers) stanowią dziś zaplecze władzy mediów elektronicznych, korpus porządkowy oraz prewencję i jednostki sprzątające w jednym. Przystąpienie do takiego grona nie wiąże się zwykle z żadnym wysiłkiem (poza koniecznością zarejestrowania swoich danych w określonym miejscu Sieci) lub co najwyżej stanowi nagrodę za aktywność traktowaną jako wymagającą gratyfikacji w sieciowym świecie (np. przestrzeganie netykiety, poruszanie się w ramach nadanych uprawnień). Tak nabywamy pewną „ilość” władzy w Sieci. Dość niewielką i mało znaczącą,

${ }^{9}$ Por. M. Castells, Władza komunikacji, Warszawa 2013.

${ }^{10}$ M. Baranowski, Przyczynek do krytyki społeczeństwa sieciowego..., s. 27. 
poza tym jednym fragmentem Sieci, w którym zostaliśmy nią obdarowani. Władza w Sieci ma bowiem charakter ilościowy, kumulatywny - jest sumą uprawnień, posiadanych adresów, powiązań, wystąpień i powtórzeń, programów (służących rozprzestrzenianiu się w Sieci) oraz algorytmów pracujących na promowanie czyjejś marki i zwierzchności w możliwie wielu punktach Internetu. Każda nowa technologia (np. urządzenia mobilne) lub rodzaje miejsc sieciowych (np. media społecznościowe) to nowy obszar, którego anektowanie oznacza zwykle konieczność inaugurowania działań w świecie rzeczywistym, nawet jeśli można do nich nabyć prawo przez przyjęcie zobowiązań, wykonanie przelewu bezgotówkowego lub wymianę wirtualnej waluty, produktu czy usługi. Z uwagi na ciągły ruch, fluktuacje i namnażanie się cyfrowych dóbr wojnom o władzę w Sieci nie byłoby końca, gdyby nie sektor usług stabilizujących posiadanie, wartość i trwanie tego, co ma postać wyłącznie elektroniczną. Branża ta towarzyszy rozwojowi Sieci od samego początku, ale dopiero w ostatniej dekadzie obserwujemy tak natężone przenikanie rozwiązań w pełni wirtualnych (z początku) do świata realnego, w celu koordynowania i stabilizowania władzy na granicy obu światów ${ }^{11}$. W największym uproszczeniu można powiedzieć o ewolucji - od programów śledzących ruch w Sieci po systemy inwigilacji; od systemów zarządzania treścią i relacjami w Sieci do technologii nadzorowania populacji; od kontroli i dyscyplinujących spojrzeń po rozproszenie świadomości tego, kto, gdzie i kiedy patrzy. Władza w Sieci to bowiem także pozorna nieobecność i niedostępność dla innych, umiejscowienie, którego może nawet nie znać sam prominent (vide maskowanie numeru IP, szyfrowanie połączeń i przesyłu pocztowego, fizyczna lokalizacja serwera, system przekierowań).

Globalność tych systemów nie jest jednak novum. Wspierane rozwojem nauki ambicje eugeniczne i psychometryczne Francisa Galtona, antropometria, technologie satelitarne, doktryny demograficzne, standaryzacja zasad produkcji żywności i lekarstw, oznaczeń i infografik w różnych obszarach życia, a nawet kultura popularna od zawsze - choć nie zawsze o takim samym natężeniu, metodach i zasięgu wpływu na populację - oddziaływały na ludzkość jako zbiór, którego nieprzeliczalność i niekontrolowalność wprawiała w zakłopotanie dysponentów władzy. Możliwość ustanowienia pewnego standardu, umasowienia, a zatem wytworzenia pewnej płaszczyzny porównawczej dla wszystkich jednostek i grup, dała „zarządcom populacji” nowe sposoby porządkowania i nadzorowania ludzkich zbiorowisk, ich

11 Z. Bauman, D. Lyon, Płynna inwigilacja: rozmowy, Kraków 2013. 
ruchu oraz przyrastania lub wymierania ${ }^{12}$. Tym sposobem możliwe stało się dokładniejsze określanie wyliczeń ekonomicznych, standardów pracowniczych, przewidywań politycznych i kalkulacji w różnych systemach, dla których zmienną stały się własności życia człowieka (zdrowie, masa mięśniowa, wiek, przebyte choroby, predyspozycje, wykształcenie itd.) oraz powiązane z nimi zmienne środowiskowe (miejsce zamieszkania, pochodzenie, obywatelstwo, numery identyfikacyjne itd.) o niekończących się możliwościach wytwarzania dodatkowych powiązań i zależności. Sieć i jej rozwój dodały do tego tysiące nowych czynników i „zmiennych”, ale także umożliwiły nowe skodyfikowanie dotychczasowych porządków i standardów oraz ich natychmiastowe wywoływanie i porównywanie. Liczba opcji optymalizacyjnych w tym zakresie wydaje się dziś nieskończona.

Technologie zarządzania populacją są zatem zorientowane na umasowione jednostki, zestandaryzowane grupy oraz dopasowywanie do standardów wszelkich nowych konwencji, figuracji i postaci, z jakimi przyjdzie im się zetknąć. Wielość form życia społecznego ulega zawsze redukcji w efekcie procesu aktualizacji, jaki przechodzą programy zarządzania populacją - wystarczy inaczej dopasować do siebie dotychczasowe zmienne lub wprowadzić nowe. „Wszystkożerność” mediów elektronicznych, do niedawna postrzeganych jako ostoja wolności, stała się dziś „,siecią” (web), w której dużo łatwiej pozyskiwać, standaryzować i wstrzymywać ruch informacji, niż jest to możliwe w rzeczywistości, w świecie fizycznym. Słynne powiedzenie: „nie ma cię w Google, więc nie istniejesz” nabiera nowego znaczenia w kontekście uciekania od nowych form władzy i jej sprawowania do enklaw rzeczywistości posiadających ograniczony dostęp (lub nieposiadających go w ogóle) do mediów elektronicznych, zwłaszcza sieciowych. W czasach gdy społeczeństwo informacyjne coraz bardziej zbliża się do „społeczeństwa sieciowego”, możliwie silnie wyizolowanego z tego, co nie może mieć postaci cyfrowej lub gwarantować przeżycia w tej postaci, niezwykle skomplikowanym i długotrwałym procesem staje się kreowanie, przetwarzanie i wymiana informacji (jakichkolwiek) poza środowiskami cyfrowymi. Informacja - w swoim aspekcie produktowym - zdominowując świat społeczeństwa informacyjnego, została wyizolowana ze świata w dotychczasowej formie, który jednak (choć endemicznie) przetrwał w różnych zakątkach planety. Czy nowe technologie zarządzania populacją pozwolą także na opanowanie tych przetrwalnikowych środowisk?

${ }_{12}$ Por. N. Strange, Zasłona dymna. Jak naginać fakty i liczby do swoich potrzeb, Gliwice 2008; P. Ball, Masa krytyczna. Jak jedno z drugiego wynika, Kraków 2007. 
Jeśli uzmysłowimy sobie, że najdoskonalszą postacią informacji mogłaby być czysta energia, a zatem redukcja materii wyłącznie do jej przekaźnika, to niewykluczone, że porzucając klasyczne twierdzenia o nieczasowości i nieprzestrzenności informacji, można będzie rozciągnąć władzę nad populacją w jeszcze większej liczbie aspektów, czego konsekwencją będzie cyfryzacja życia i dalsze usieciowianie form jego kontroli ${ }^{13}$.

Środowisko naukowców nie prezentuje jednolitego stanowiska w kwestii oceny społecznych konsekwencji stosowania zaawansowanych technologii typu real-time data analysis, ponieważ owe technologie funkcjonują w wielopłaszczyznowej strukturze, która nie daje się jednoznacznie zaklasyfikować.

[...] niektórzy badacze twierdzą, iż zdecentralizowana organizacja Internetu pozwala na pojawienie się oddolnych, bezpośrednio demokratycznych społeczności, które kwestionują centralizację władzy, i tym samym umożliwia ustanowienie społeczeństwa partycypacyjnego. Inni utrzymują, że global networked information space umożliwia powstanie totalitarnych form nadzoru i kontroli ${ }^{14}$.

W rzeczy samej społeczności sieciowe skutecznie organizują się za pomocą wspomnianych technologii, jak chociażby „usieciowione ruchy społeczne”"15 a zarazem te same podmioty, jako część dużo szerszych całości, podlegają „,niewidzialnym”, ale realnym i skutecznym formom nadzoru. Sam nadzór, podobnie jak sposoby jego wykorzystania, różni się zasadniczo od „klasycznych” form sprawowania władzy. Wiąże się raczej z „działaniem w tle”, ciągłą analizą dużych porcji informacji za pomocą specjalnie skonstruowanych algorytmów, ale jego oddziaływanie - choć często przybiera

${ }^{13}$ Problem ten wydaje się szczególnie interesujący w kontekście, z jednej strony, klęski projektów sztucznej inteligencji (AI) rozwijanych od końca lat 50. XX wieku i twierdzeń Norberta Wienera o utożsamianiu „informacji” z „treścią”, które mogą okazać się sofizmatyczne w kontekście dalszego rozwoju technologii (np. kwantowych), z drugiej zaś - słynnego zdania Marshalla McLuhana, że „medium jest przekazem”, która to maksyma, wielokrotnie ignorowana i pobłażliwie traktowana przez naukowców społecznych kilku dekad, urasta do rangi zdania niezwykle przenikliwego z uwagi na dalsze możliwości rozwoju sieciowych form sprawowania władzy nad populacją. Por. N. Wiener, Cybernetyka a społeczeństwo, Warszawa 1961; A. Kisielewicz, Sztuczna inteligencja i logika. Podsumowanie przedsięwzięcia naukowego, Warszawa 2011; M. McLuhan, Wybór tekstów, Poznań 2001.

${ }^{14}$ Ch. Fuchs, Transnational Space and the „Network Society”, „21 $1^{\text {st }}$ Century Society” $1(2) / 2007$, s. 71.

${ }_{15}$ M. Castells, Sieci oburzenia i nadziei. Ruchy społeczne w erze Internetu, Warszawa 2013. 
postać biernego rejestrowania - jest realne i w momencie zastosowania staje się bardziej skuteczne niż jakiekolwiek inne metody wykorzystywane wcześniej. Skala stosowania prewencyjnego nadzoru nie jest znana, a mówiąc ściślej - nie może być znana, zaś badacze społeczeństw sieciowych mogą co najwyżej szacować jego zakres, opierając się na cząstkowych badaniach lub zwykłych „przeciekach”. Z tych ostatnich

[...] dzięki informacjom ujawnionym przez Edwarda Snowdena i Gleena Greenwalda i podanym do wiadomości publicznej przez dziennik The Guardian wiemy, że większość kolosów Internetu była - i nadal jest - współodpowiedzialna za powszechną inwigilację obywateli przez amerykańską Agencję Bezpieczeństwa Narodowego (NSA): zapewnia jej dostęp do portali społecznościowych i umożliwia wdrożenie nielegalnego oprogramowania szpiegowskiego, monitorującego komunikację e-mailową i telefoniczną ${ }^{16}$.

Formy nadzoru nie ograniczają się wyłącznie do rejestrowania informacji z przeglądarek, portali społecznościowych czy internetowych sklepów. Totalność nowych technologii, będąca konsekwencją digitalizacji większości obszarów funkcjonowania podmiotów w społeczeństwie, dotyczy również informacji na temat stanu zdrowia i przebytych chorób (także potencjalnych obciążeń genetycznych), struktury wydatków, preferencji politycznych i światopoglądowych czy stałej lokalizacji i inwigilacji za pomocą BTS-ów (Base Transceiver Stations). Nowe technologie sieciowe (poprzez upowszechnianie określonych standardów, czyli także obniżanie ich kosztów) są niezwykle szybko adaptowane do przeróżnych obszarów rzeczywistości społecznej (od miejsca pracy i nauki do wypoczynku i konsumpcji włącznie). Obejmują tak zaawansowane projekty jak sieci semantyczne (Semantic Web) albo tak praktyczne jak wykorzystanie dronów do monitorowania transportów PKP Cargo oraz w usługach transportowych (np. Amazon). Co więcej, w skali świata istnieje przynajmniej kilkanaście zintegrowanych systemów zarządzania/kontroli o zasięgu aglomeracji miejskiej lub regionu, czego przykładem może być londyński Ring of Steel (rozwijany już od początku lat 90 . XX wieku jako jeden z elementów walki z członkami IRA) czy też LMSC (Lower Manhattan Security Initiative). Na podobnych zasadach odbywa się monitorowanie przestrzeni powietrznych państw europejskich, ale i wybiórcze sekwencjonowanie analiz poruszania się obywateli (np. rejestrowanych przez audiowizualny monitoring miejski CCTV, wspierany przez technologie pattern recognition, tj. rozpoznawania

${ }^{16}$ I. Ramonet, Wszyscy jesteśmy pod lupq, „Le Monde Diplomatique” 2014, http:// monde-diplomatique.pl/LMD100/index.php?id=1_3 [16.12.2014]. 
wzorców). W produkcji tych ostatnich specjalizują się komercyjne podmioty, anektujące różne szczegółowe dziedziny w ramach przywołanej technologii, np. ANPR ${ }^{17}$ (systemy rozpoznawania tablic rejestracyjnych Automatic Number Plate Recognition, produkowane m.in. przez NDI Recognition Systems, QRO Solutions czy węgierski system CARMEN Free Flow firmy ARH Inc.), IMSI catcher (systemy International Mobile Subscriber Identity do podsłuchiwania, przechwytywania i śledzenia sygnałów w telefonach komórkowych, np. Sting Ray firmy Harris Corporation czy MicroNet firmy Proximus), mikrochipy z technologią RFID (Radio-Frequency Identification), znajdujące coraz szersze zastosowanie w biomedycynie i biometryce (produkty VeriTeQ, Impinj, Alien Technology i NXP) oraz wiele, wiele innych. Wszystkie one oparte są na filozofii „dostrzegania” powiązań, kontynuacji, powtarzalnych sekwencji, pozwalających doskonalić statystyczne przewidywania oraz zmniejszać odległość (czasową, ilościową, stopni) między poszczególnymi węzłami. Prowadzą zatem do „zagęszczenia” sieci danych oraz ich postępującej nadprodukcji, skutkującej inflacją informacji.

Związany z tym problem namnażania danych (big data), z jakim mierzy się współczesny świat, prowadzi zwrotnie do - oprócz produkcji wysoce wyspecjalizowanych i koherentnie zintegrowanych narzędzi inwigilacji - dywersyfikowania form monitorowania „elektronicznej nadprodukcji” danych. Przykłady takich systemów, jak ECHELON ${ }^{18}$, PRISM czy Carnivore/Omnivore, doskonale obrazują ich „niepodległość” w zakresie podporządkowywania się scentralizowanym formom władzy transnarodowej (dwa pierwsze pozostają podporządkowane decyzjom NSA, Agencji Bezpieczeństwa Narodowego USA, a trzeci, stosowany w latach 1997-2001 przez FBI, został zastąpiony przez komercyjne systemy, np. Narus Insight). Żaden z nich nie służy interesom globalnych wspólnot, lecz pojedynczych państw lub podmiotów gospodarczych, a przepływ informacji między nimi każdorazowo wywołuje trudności z racji istnienia sprzecznych interesów społeczno-politycznych i gospodarczych pomiędzy aktantami procesów inwigilacji ${ }^{19}$. Działania tych systemów częstokroć stanowią wyraz zaburzania

${ }^{17}$ http://www.itsinternational.com/categories/detection-monitoring-machine-vision/ features/growth-of-anpr-applications-for-enforcement-tolling-and-more/ [16.12.2014].

${ }^{18}$ ECHELON określany jest jako „globalny system nasłuchu prywatnej i komercyjnej łączności”. Por. Report on the existence of a global system for the interception of private and commercial communications, http://www.europarl.europa.eu/sides/getDoc.do?pubRef $=-/ / \mathrm{EP} / / \mathrm{NONSGML}+\mathrm{REPORT}+\mathrm{A} 5-2001-0264+0+\mathrm{DOC}+\mathrm{PDF}+\mathrm{V} 0 / / \mathrm{EN} \&$ language $=\mathrm{EN}$ [16.12.2014].

19 Doskonałą ilustracją tej tezy jest „afera podsłuchowa PRISM”, ujawniona w 2013 r. m.in. na bazie dokumentów udostępnionych przez Edwarda Snowdena. Por. http://prawo. 
polityki balance of power, łamią protokół dyplomatyczny oraz naruszają swobody obywatelskie, pochodzące z nadania organizacji międzynarodowych (np. Unii Europejskiej), na rzecz interesów jednego aktora - konkretnego państwa, agencji rządowej lub korporacji. W tym sensie technologie i mechanizmy służące wytwarzaniu władzy kapilarnej, rozproszonej i horyzontalnej, często wzmacniają wertykalne struktury władzy. Każdy podmiot w strukturze globalnych powiązań władzy dąży bowiem do zachowania dla siebie pewnej jej części, autonomicznego sposobu jej sprawowania, który jest niezbędny do nadzorowania innych systemów i pracy innych węzłów siatki władzy. Autarkiczność tych systemów jest zatem wyłącznie pozorna. Jak nakazują sądzić różne teorie sieciowości, mają one sens jedynie jako całość powiązanych elementów; „potrzebują się” nawzajem, aby odkrywać szlaki, po jakich podróżują informacje, które pozwalają lokalizować wydarzenia, ludzi, przedmioty, zjawiska. To samodoskonalący się mechanizm, w który zostaje uwikłana rywalizacja o zakres władzy, dzięki czemu system dąży do ciągłego rozwoju, choć jest on nieregularny; mechanizm ten stanowi bowiem funkcję progresu najlepiej i najgorzej rozwiniętego systemu inwigilacyjnego. W pewnym sensie technologie te powinny zatem wykazywać właściwości systemu autopojetycznego w rozumieniu Niklasa Luhmanna ${ }^{20}$. „Rozproszona władza” jest jednak tylko ideą, a jej horyzontalność - umowną konwencją, której pragmatyczne, inżynieryjne wykonanie blokowane jest przez układ interesów ogromnej liczby dysponentów fragmentarycznej władzy ${ }^{21}$. Jej skomasowanie wymagałoby zatem rezygnacji przez każdego z aktorów z części przysługujących mu prerogatyw w zakresie sprawstwa i wywierania wpływu na inne podmioty (innych aktorów) w celu wygenerowania swobodnego przepływu danych do każdego węzła sieci władzy²2. Z uwagi jednak na istnienie węzłów „silniejszych” i „słabszych”, zróżnicowanych między sobą w zakresie ilości władzy, którą mogą dysponować,

money.pl/aktualnosci/wiadomosci/artykul/afera;prism;merkel;podsluchiwanie;przyjaciol; tak;byc;nie;moze,109,0,1338989.html [16.12.2014].

${ }^{20}$ N. Luhmann, Systemy społeczne. Zarys ogólnej teorii, Kraków 2007, ss. 40-43 nn.

${ }^{21}$ Stąd też „sieciowe” teorie władzy (M. Castells, M. S. Granovetter, G. Manzo) abstrahują w swoim rozumieniu „rozproszenia” od Foucaultowskiej „kapilarności” i „bycia wszędzie”. Por. W.J. Drake, E.J. Wilson III (red.), Governing Global Electronic Networks. International Perspectives on Policy and Power, London - Cambridge 2008. Prym w tego rodzaju refleksji wiedzie socjologia analityczna. Por. G. Manzo, Analytical sociology. Actions and networks, Hoboken 2014.

${ }^{22}$ Idea ta wydaje się najlepiej urzeczywistniać na gruncie technologii i aktywności związanych z sousveillance. 
rywalizacja o pozyskiwanie nowych pól i metod sprawowania kontroli nie ustaje. Zabieganie o „metawładzę” (sprawowanie kontroli przez jedne węzły sieci władzy nad innymi), swoista dialektyka horyzontalnego i wertykalnego (obok integracji i dywersyfikacji) sprawowania władzy, w wymiarze inwigilacji i nadzoru, na styku tego, co rzeczywiste i wirtualne, tworzy nowe nisze dla form oporu, zwłaszcza w środowisku sieciowym.

Maskowanie IP, rozwój przestrzeni darknetu i Freenetu oraz wiele innych zjawisk o proweniencji cyfrowej pokazują, jak (pozornie) niedoskonały (a najczęściej żaden) jest przepływ informacji pomiędzy systemami inwigilacji elektronicznej. Działania usytuowane na „przedpolach” władzy (gdzie spada skuteczność form nadzoru i kontroli), w nowych miejscach sieci oraz w tych pozornie nieistniejących (maskowanych), gdzie przecinają się uprawnienia różnych służb i zakresy oddziaływania różnych algorytmów surveillance software, wymagają nieopłacalnej (ze strony węzłów sieci władzy) mobilizacji różnych zasobów oraz współdzielenia się władzą nad sieciowymi „terytoriami” z innymi węzłami/aktorami. Formy sieciowego oporu przeciw „wszechwidzącej” władzy stanowią także siłę napędową psychosocjologicznych mechanizmów wycofania i zaprzestania uczestnictwa w życiu „usieciowionych społeczeństw”: od porzucenia korzystania z mediów społecznościowych, przez ruchy na rzecz swobodnego dostępu do danych (open data), aż po - coraz trudniejszą w czasach dominacji nawigacji satelitarnej - izolację terytorialną w najmniej dostępnych miejscach globu. Dla części aktorów społecznych wręcz odwrotnie - cyfrowy opór stanowi impuls do formowania działań w świecie rzeczywistym, ,pozaelektronicznym" (w znaczeniu usytuowania poza - lub bardziej: obok - Internetu). Przeróżne formy „nadzoru obywatelskiego” (sousveillance), poczynając od „nagrywania nagrywających”23, whistleblowingu (szczególnie popularnego za sprawą takich serwisów, jak WikiLeaks ${ }^{24}$ czy Cryptome.org ${ }^{25}$ ) lub roz-

${ }^{23}$ Czy też: „Śledzenia śledzących”. Mieści się tu zarówno nagrywanie kamerą pracy funkcjonariuszy publicznych (np. policji i straży miejskiej), jak i oprogramowanie typu Lightbeam - „wtyczka” do przeglądarki internetowej Mozilla Firefox, która pozwala na „interaktywne wizualizacje przedstawiające interakcje z witrynami odwiedzanymi bezpośrednio oraz pośrednio. Podczas zwykłego przeglądania Lightbeam odsłania pełną złożoność dzisiejszej Sieci, łącznie z tymi jej częściami, które przeważnie nie są zbyt przejrzyste dla przeciętnego użytkownika” (https://www.mozilla.org/pl/lightbeam/ [16.12.2014]). Reklamowana hasłem „Rzuć trochę światła na obserwujących” pozwala na podglądanie, gdzie i do kogo wędrują pakiety informacji sieciowych, które przeglądamy, i kto przegląda je dalej.

\footnotetext{
${ }^{24}$ https://wikileaks.org/ [16.12.2014].

${ }^{25}$ http://cryptome.org/ [16.12.2014].
} 
woju „dziennikarstwa obywatelskiego”26, aż po umieszczanie w domenie publicznej loginów i haseł dostępowych do „czystych” (niezablokowanych) kont, umożliwiających przeglądanie zastrzeżonych dostępów sieciowych ${ }^{27}$ i rozwój branży produkującej technologiczne gadżety z tym związane ${ }^{28}$, przywołują na myśl złożoność i wielość technologii spod znaku surveillance. Także w obrębie sousveillance mamy do czynienia ze zintegrowanymi systemami nadzoru oraz kontroli, które niwelują różnicę pomiędzy światem cyfrowym a realnym równie skutecznie, co rozwiązania prosystemowe, np. akcje podejmowane przez członków i sympatyków ruchu Anonymous w różnych zakątkach świata. Warto nadmienić, że to właśnie tym ostatnim przykładom najbliżej do urzeczywistnienia idei władzy rozproszonej, zdecentralizowanej, którego to potencjału nie mają często „oficjalne” (rządowe lub korporacyjne) formy inwigilacji. Z podobną filozofią spotykamy się jednak coraz częściej, m.in. na rynkach produkcji oprogramowania komputerowego, gdzie sztandarowym przykładem jest opozycja między systemem operacyjnym Windows (scentralizowane wytwarzanie produktu, usprawnień, konieczność przekazywania firmie Microsoft autorskich „łatek” systemowych itd.) a Linux (darmowy dostęp, oparcie o filozofię FreeLibre/ Open Source Software, zgodnie z którą kod źródłowy programu można dowolnie modyfikować i rozpowszechniać). O ile w przypadku działań Anonymous i podobnych grup decentralizacja oraz horyzontalne rozproszenie dysponentów informacji (za którą, w świecie cyfrowym zwłaszcza, podąża władza) podyktowane są względami bezpieczeństwa (trudność w lokalizowaniu i likwidowaniu poszczególnych węzłów tej struktury), o tyle w przypadku produkcji oprogramowania są to względy czysto ekonomiczne, związane z lojalizowaniem klientów oraz możliwością outsourcingowania kosztów rozwoju i ewentualnej restrukturyzacji produktu, a także opóźniania jego „starzenia się” poprzez wykorzystanie „mądrości tłumów”29. W obu przypadkach (sousveillance i decentralizacji produkcji w sektorze IT) wytwarzane są zatem struktury, które (niekiedy) zaczynają stanowić znaczącą przeciwwagę dla oficjalnych systemów kontroli i nadzoru, czyniąc aspiracje do pełnej kontroli nad obywatelami świata mrzonką. Przynajmniej

${ }^{26}$ L.A. Lievrouw, Media alternatywne i zaangażowane społecznie, Warszawa 2012.

27 Przykładem takich serwisów jest BugMeNot, http://bugmenot.com/ [16.12.2014].

${ }^{28}$ Przykładem może być projekt MemotoLifeloggingCamera, który powstał dzięki donacjom pochodzącym z serwisu crowdfundingowego Kickstarter w 2012 r. Por. https:// www.kickstarter.com/projects/martinkallstrom/memoto-lifelogging-camera [16.12.2014].

29 J. Surowiecki, Mądrość tłumu. Większość ma rację w ekonomii, biznesie i polityce, Gliwice 2010. 
takie mogą pojawiać się intuicje, gdyż zakres i sposób działania owych systemów nie jest znany. Trudno przy tym wyeliminować teoretyczny argument, że mechanizmy przeciwwagi są nie tylko nieskuteczne, ale wręcz mogą służyć celom przeciwstawnym (sousveillance staje się surveillance, tzn. ten, który kontroluje, nieintencjonalnie dostarcza informacji systemom kontrolującym).

Zarówno jednak ukrywanie się, jak i podejmowanie działań „w” sieci, czy chroniczne przebywanie „poza” jej obrębem nie przechyla szali na żadną ze stron. Istotą „usieciowienia” jest bowiem posiadanie władzy i bycie władzy podporządkowanym; ciągłe przechodzenie pomiędzy cyklami inkluzji i ekskluzji, obserwowanie i bycie obserwowanym. Różnicę w tym względzie stanowi jedynie skala i zakres kontroli, gdyż władza w sieci (a nawet szerzej: we współczesnym społeczeństwie sieciowym) ma charakter ilościowy, kumulatywny. Swoista równowaga między obywatelskim i oficjalnym nadzorem, a także mechanizmami inwigilacji staje się nieodłącznym elementem naszej rzeczywistości, przenikając również do praktyki życia codziennego, czego efektem jest produkcja różnego rodzaju gadżetów i technologii usprawniających formy kontroli w perspektywie mikrospołecznej. Podsłuchy, urządzenia namierzające telefony komórkowe (np. aplikacje instalowane w telefonach dzieci przez rodziców) i długopisy z wbudowanymi kamerami, czyli „urządzenia szpiegujące na każdą kieszeń”, to sektor usług, którego rozkwit poprzedzony był upowszechnieniem się takich wynalazków, jak elektroniczne nianie, monitory oddechu czy dźwiękowe lokalizatory małych przedmiotów (np. kluczy) dla osób starszych czy chorych (np. na Alzheimera). Produkty te nie są niczym więcej jak odpowiedzią na zgłaszane zapotrzebowanie zwiększania kontroli w najbliższym sobie środowisku życia (co wiąże się z poczuciem braku wpływu na sprawy o szerszym horyzoncie oddziaływania, w recepcji ogólnospołecznej uznawane za całkowicie nie do podporządkowania/zrozumienia z perspektywy jednostki, np. „świat wielkiej polityki”). Dzięki nim jednostki nadzorują się same; ulegają przymusowi wyrabiania w sobie nawyków (wyszukiwania, lokalizowania, pozyskiwania itd.), które umożliwiając egzystowanie w sieci, coraz częściej stają się obowiązkowe, by egzystować w realnym, pozawirtualnym społeczeństwie, którego „usieciowienie” należy rozumieć jako wprowadzenie nowej organizacji życia społecznego i nowych porządków symbolicznych na różnych jego szczeblach. Upodobnienie życia elektronicznego do realnego, choć droga rozwoju związanych z tym technologii od początku była odwrotna (chodziło od odwzorowanie realnego życia w przestrzeni cyfrowej), staje się dziś niezaprzeczalnym faktem przy 
opisywaniu kondycji współczesnych społeczeństw. Inwigilacja i nadzór nie są dziś zatem wyłącznie systemami kontroli sprawującymi władzę (surveillance) czy danej władzy podporządkowanymi (sousveillance), ale także zbiorem aktywności, w których uczestniczy większość grup społecznych na terenie wielu państw świata, choć o różnym zakresie wpływu na inne agendy sprawowania i wykonywania władzy. Współczesny wymiar społeczeństwa sieciowego, ujmowany bardzo intuicyjnie (przede wszystkim za sprawą „niewidzialności” technologicznego wymiaru kontroli), może prowadzić do konkluzji, iż władzę ma dziś każdy - choć o innym zasięgu oddziaływania i mocy. Staje się ona wyrazem pierwotnej dążności do nazywania elementów świata i panowania nad nimi. Nawet jeśli w skali ogólnospołecznej jest to jedynie pozór kontroli, co wydaje się więcej niż prawdopodobne, to w perspektywie mikrospołecznej może on pełnić istotną rolę w socjalizowaniu do życia w społeczeństwie sieciowym. Jednak nie o (samo)satysfakcję jednostek-węzłów toczy się ta z gruntu nierówna walka o przejrzystość nowoczesnych struktur władzy i panowania. Stawka tej batalii jest o wiele większa, gdyż dotyczy wszystkich poziomów funkcjonowania jednostek w społeczeństwie, których nie sposób ograniczyć do jednego ośrodka sterowania czy jednego zestawu celów. Chodzi zarazem o obszar kultury (z wzorcami konsumpcyjnymi czy edukacyjnymi), polityki (fasadowość systemów demokratycznych i ich niezależność od społecznych form kontroli) oraz gospodarki (dominacja neoliberalnej opcji z neofordystycznym modelem pracy), które współkształtują formy relacji społecznych.

\section{Literatura}

Ball P., Masa krytyczna. Jak jedno z drugiego wynika, Kraków 2007.

Baranowski M., Przyczynek do krytyki społeczeństwa sieciowego: od sieci społecznych do sieci wszystkich sieci, w: M. Baranowski, B. Mika (red.), Społeczeństwo sieciowe między wolnościq a zniewoleniem, Poznań 2012.

Bauman Z., Lyon D., Płynna inwigilacja: rozmowy, Kraków 2013.

Castells M., Sieci oburzenia i nadziei. Ruchy społeczne w erze Internetu, Warszawa 2013.

Castells M., Władza komunikacji, Warszawa 2013.

Drake W.J., Wilson E.J. III, Governing Global Electronic Networks. International Perspectives on Policy and Power, London - Cambridge 2008.

Foucault M., Bezpieczeństwo, terytorium, populacja. Wykłady z Collège de France 1977/1978, Warszawa 2010.

Foucault M., Narodziny biopolityki. Wykłady z Collège de France 1978/1979, Warszawa 2012.

Foucault M., Rzq̨dzenie żywymi. Wykłady z Collège de France 1979/1980, Warszawa 2014. 
Fuchs Ch., Transnational Space and the „Network Society”, „21 $21^{\text {st }}$ Century Society” 1(2)/ 2007.

Gleick J., Informacja. Bit, wszechświat, rewolucja, Kraków 2012.

Gleick J., Szybciej. Przyspieszenie niemal wszystkiego, Poznań 2003.

Hobbes T., Lewiatan, Warszawa 2005.

Jonscher Ch., Życie okablowane. Kim jesteśmy w epoce przekazu cyfrowego?, Warszawa 2001.

Kisielewicz A., Sztuczna inteligencja i logika. Podsumowanie przedsięwzięcia naukowego, Warszawa 2011.

Lievrouw L.A., Media alternatywne i zaangażowane społecznie, Warszawa 2012.

Luhmann N., Systemy społeczne. Zarys ogólnej teorii, Kraków 2007.

Manzo G., Analytical sociology. Actions and networks, Hoboken 2014.

McLuhan M., Wybór tekstów, Poznań 2001.

Moore W., Futurecities - the survival of the fastest, Institute of Directors, http://www.iod. com/ /media/Documents/PDFs/Influencing/Big\%20Picture/BP\%202012/futurecitiesthesurvivalofthefastestdec12.pdf [16.12.2014].

Mucha J., Müller K., Ralfa Dahrendorfa konfliktowa wizja społeczeństwa. Wprowadzenie do Klas i konfliktu klasowego w społeczeństwie przemysłowym, w: R. Dahrendorf, Klasy i konflikt klasowy w społeczeństwie przemysłowym, Kraków 2008.

Nawratek K., Dziury w całym. Wstęp do miejskich rewolucji, Warszawa 2012.

Ramonet I., Wszyscy jesteśmy pod lupq, „Le Monde Diplomatique”, http://monde-diplomatique.pl/LMD100/index.php?id=1_3 [16.12.2014].

Report on the existence of a global system for the interception of private and commercial communications, http://www.europarl.europa.eu/sides/getDoc.do?pubRef=-// $\mathrm{EP} / / \mathrm{NONSGML}+\mathrm{REPORT}+\mathrm{A} 5-2001-0264+0+\mathrm{DOC}+\mathrm{PDF}+\mathrm{V0} / / \mathrm{EN} \&$ language $=\mathrm{EN}$ [16.12.2014].

Strange N., Zasłona dymna. Jak naginać fakty i liczby do swoich potrzeb, Gliwice 2008.

Surowiecki J., Mądrość tłumu. Większość ma rację w ekonomii, biznesie i polityce, Gliwice 2010.

Weber M., Gospodarka i społeczeństwo. Zarys socjologii rozumiejq̨cej, Warszawa 2002.

Wiener N., Cybernetyka a społeczeństwo, Warszawa 1961.

http://bugmenot.com/ [16.12.2014].

http://cryptome.org/ [16.12.2014].

http://prawo.money.pl/aktualnosci/wiadomosci/artykul/afera;prism;merkel;podsluchiwanie;przyjaciol;tak;byc;nie;moze,109,0,1338989.html [16.12.2014].

http://www.itsinternational.com/categories/detection-monitoring-machine-vision/features/ growth-of-anpr-applications-for-enforcement-tolling-and-more/ [16.12.2014].

https://wikileaks.org/ [16.12.2014].

https://www.kickstarter.com/projects/martinkallstrom/memoto-lifelogging-camera [16.12. 2014].

https://www.mozilla.org/pl/lightbeam/ [16.12.2014]. 